\title{
NOTE
}

\section{Hyperplastic growth of mucous cells in the mantle of the mussel Modiolus kurilensis from a heavily polluted area of Amursky Bay, Sea of Japan}

\author{
L. N. Usheva*, N. A. Odintsova \\ Institute of Marine Biology, Far East Branch of Russian Academy of Science, 690041, Vladivostok, Russia
}

\begin{abstract}
The histology of an external mantle growth in 1 of 500 Modiolus kurilensis from a heavily polluted area of Amursky Bay, Sea of Japan, was described. The growth consisted of subepithelial basophilic mucous cells containing glucosaminoglycans, eosinophilic large-granular cells with proteins and neutral polysaccharides, and mixed (acid + neutral mucopolysaccharides) cell types. Some subepithelial eosinophilic and basophilic gland cells were dividing and seemed to be the source of tumor growth. The mitotic index of growth cells reached $0.5 \%$ on some growth sections; however, many mitoses were pycnotic. The emergence of the tumor on the mussel mantle is probably related to a compensatory or regenerative hyperplasia of subepithelial mucous cells.
\end{abstract}

KEY WORDS: Mussel - Mantle - Hyperplasia - Mucous cells · Mitotic index

External polypoid growths consisting of epithelial gland cells have been found on the foot or the mantle of some freshwater and marine gastropod and bivalve molluscs (Pauley 1967, 1968, 1969, Sparks 1985). Growths were usually hyperplastic and rarely neoplastic (Pauley \& Sayce 1972). This paper decribes the histology of an external mantle hyperplastic polypoid growth of Modiolus kurilensis from Amursky Bay, Sea of Japan, and cell sources of its emergence are discussed.

Materials and methods. 400 mussels Modiolus kurilensis (Modiolus difficilis) were collected in March 1990, 1991, 1994, 1996 from Amursky Bay, Sea of Japan, within the city precincts of Vladivostok, from the areas Pervaj and Vtoraya Rechka, which are heavily polluted by industrial and domestic sewage (Elya-

•E-mail: aisa@vld.global-one.ru kov 1992, Tkalin et al. 1993), and 100 mussels were collected in August 1995 in the relatively clear area of Vostok Bay, Sea of Japan. The external mantle tumor and its underlying tissues were fixed in phosphate buffered $10 \%$ neutral formalin with $3 \% \mathrm{NaCl}$ for $36 \mathrm{~h}$ at $4^{\circ} \mathrm{C}$. Paraffin sections ( 4 to $5 \mu \mathrm{m}$ thick) were stained with either Mayer's hematoxylin and eosin (H\&E) or methylene blue for histological differentiation. Alcian blue was further used in combinations with Periodic Acid-Schiff solution (PAS) for differentiation of neutral and acid mucopolysaccharides (acid and neutral MPS) and fast green at $\mathrm{pH} 2.2$ for total proteins (Pearse 1968)

The mitotic index (MI) was determined in cells of the growth (per 7000 cells) and in cells of protective epithelium above and near the growth (per 15000 cells and per 58000 cells, respectively) and in subepithelial mucous cells (per 10000 cells) upon examination of 7 to 13 mantle sections.

Results. A soft external horn-shaped growth of a reddish colour was revealed in 1 large old mussel (shell length about $13 \mathrm{~cm}$ ) from Vtoraya Rechka Inlet in 1990 . This unencapsulated growth, approximately $5 \times 3 \mathrm{~mm}$ in size, was located in the area of the mantle edge where 2 opposing mantle lobes and the gills fuse (Figs. $1 \& 2$ ). Many areas of the growth had an incomplete and necrotic, ciliated epithelium covering with vacuolated cell cytoplasm and hyperchromic nuclei (Fig. 3a). The mantle epithelium near the growth was normal, but apical cell cytoplasm had conspicuous basophilic grains

The growth consisted of masses of basophilic and eosinophilic cells arranged in small nodules surrounded by thin fibrous strips; there was a large nodule at the base of the growth. Most of the growth was composed of large basophilic alcianophilic vacuolated 


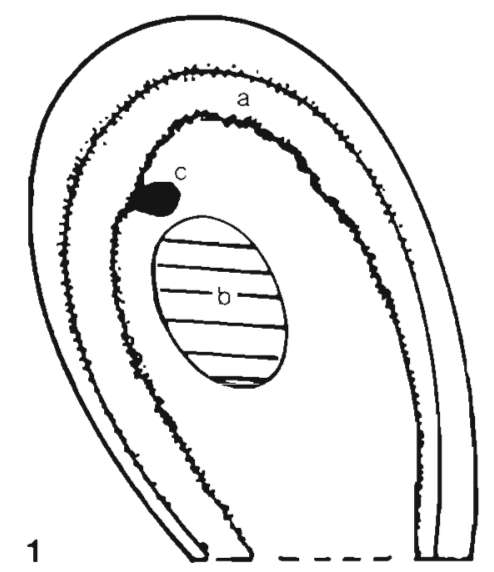

Fig. 1. Modiolus kurilensis. Location of mantle growth. a: mantle; b: adductor, c: growtin

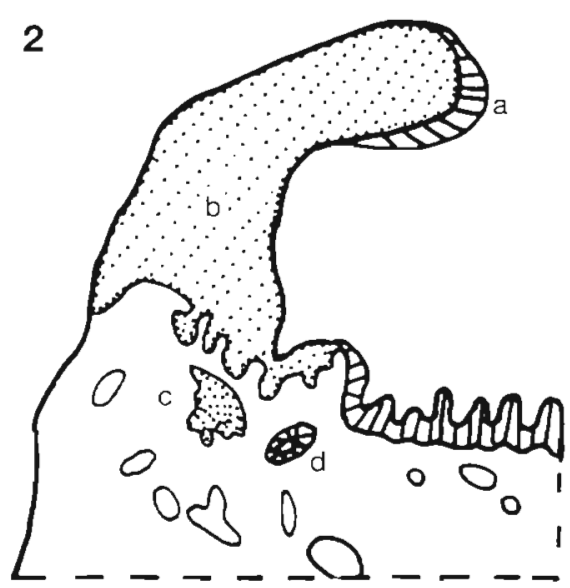

Fig. 2. Modiolus kurilensis. Structure of mantle growth section. a: epithelium covering; b: bulk of growth; c: a group of gland cells at growth base; $d$ : cross section of invagination of epithelium covering

cells (Fig. 3b) which, when metachromatically stained with methylene blue, became lilac in color and which contained mainly glucosaminoglycanes, a small quantity of neutral polysaccharides and a few protein granules. Eosinophilic large-granular cells were clearly stained blue with methylene blue and contained proteins and neutral polysaccharides. They were often compressed by swollen basophilic cells in the body of the growth. Cells had hyperchromic or pycnotic nuclei, especially in the marginal areas of the growth. Small nodules of eosinophilic large-granular cells were also found under the growth among bundles of the mantle muscle (Figs. $2 \& 3$ c) near cross sections of invaginations of the epithelium covering. There were also numerous cells containing a mixture of acid and neutral MPS. Large accumulations of vacuolized basophilic cells and of large-granular eosinophilic cells were revealed in the mantle of both growth-bearing mussels (Fig. 3b, d) and non-growth-bearing mussels. Some of these unicellular subepithelial glands had ducts. Mixed-type cells were found only in the growth itself.

At high magnification under the microscope prophases and prometaphases were found in basophilic and eosinophilic cells, mainly in the large nodus of the growth base; no obvious anaphases or telophases were found. Mitotic forms were often small, shrunken and pycnotic, which is why mitotic cells in the growth were hard to distinguish. The MI of the growth cells ranged from 0 to $0.5 \%$ on some sections of the growth; the MI of cells of the protective epithelium above the growth and that of cells near the growth ranged from 0.01 to $0.03 \%$, The $\mathrm{Ml}$ of the subepithelial mucous cells was zero.

No growth cells were found in the hemal sinuses or vessels of the mantle tissues. The muscle and connective tissues of the mussel mantle were not affected; however, the epithelium of the gill filaments was incomplete. Furthermore, no recognisable parasites were found.

Discussion. The external mantle growth examined was an abnormal accumulation of cells containing mainly acid, but also neutral and mixed mucopolysaccharides, and showing clear homology with mucous cells in the subepithelial layer of the mantle in both diseased mussels (Fig. 3b, d) and non-tumor-bearing mussels. Undifferentiated cells were not found in the growth. Dividing differentiated mucous cells seemed to be a source of the tumor growth.

Neoplastic lesions also derived from the mantle epithelium were found in a Pacific oyster and Sydney rock oysters (Wolf 1969, 1971, Pauley \& Sayse 1972). However, the mantle lesion of the mussel Modiolus kurilensis clearly differed from those of oysters. It was composed of only one epithelial cell kind (mucous cells); it had no glandular tubules and deep crypts of mantle epithelium were found only at the base of the tumor. In addition, the lesion was not invasive and, probably, its cell proliferation was controlled, because anaphases and telophases were pycnotic. Although the polypoid mantle growth on the Modiolus kurilensis examined had no muscular core or stalk, it was the same type as the polypoid growths on the foot of the freshwater mussels Anodonta cygnea, A. californiensis and Margaritifera margaritifera, which also typically showed a heavy concentration of basophilic epithelial cells beneath the epithelium (Pauley 1967, 1968, 1969). The content of the glandular cells of the mussel growth was similar to that of hyperplastic growth in the gill of Pseudanodonta complanata (Peccarinen 1993); however, the cell morphology of these growths differed considerably. 


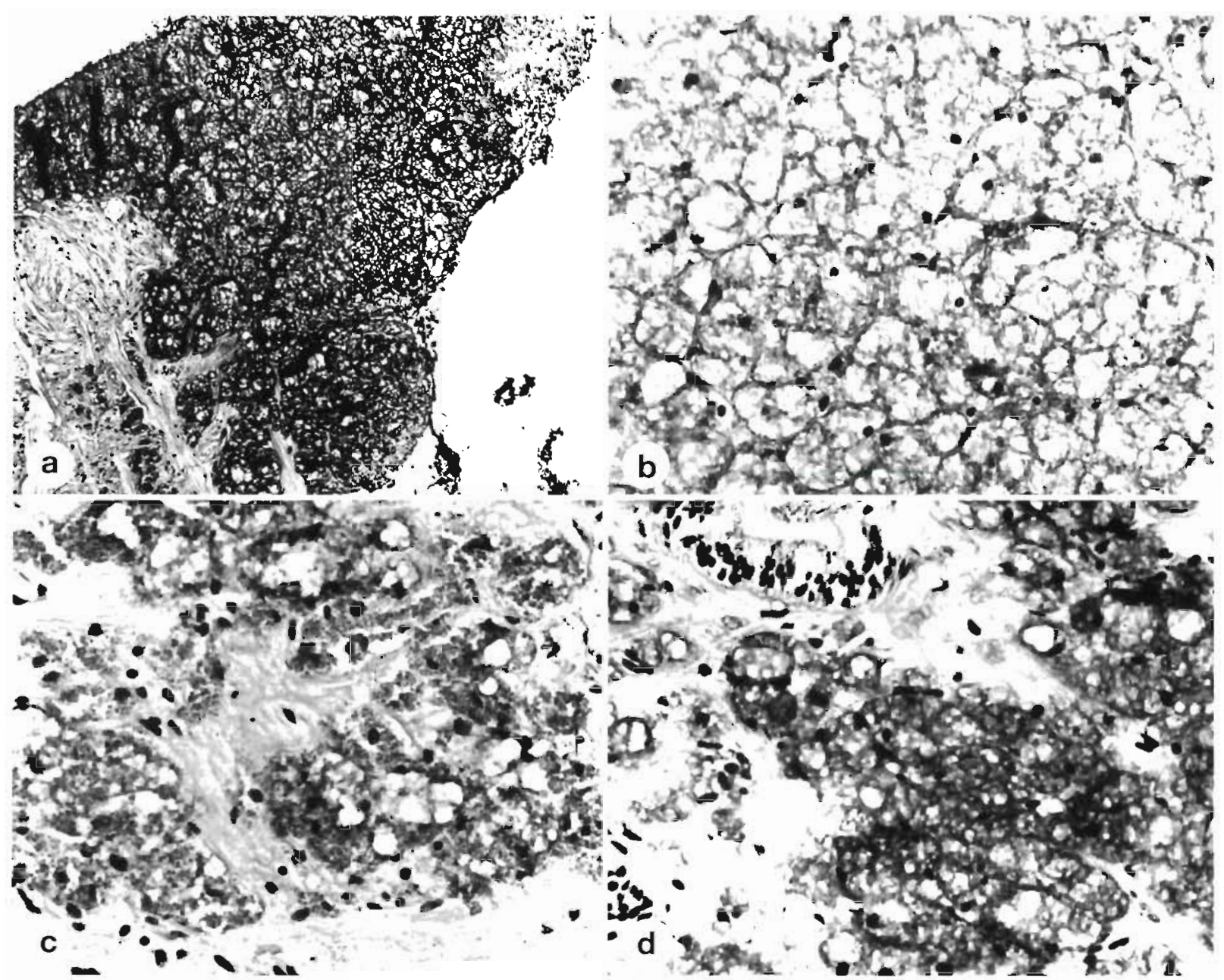

Fig. 3. Modiolus kurilensis. Histological structure of mantle growth. (a) General view of growth; visible are basophilic vacuolized cells, damaged marginal sites of growth, detached covering epithelium. H\&E, 80×. (b) Vacuolized basophilic glandular cells of growth with hyperchromic cell nuclei, H\&E, 200×. (c) Granular eosinophilic cells at growth base. H\&E, 200x. (d) Subepithelial vacuolized basophilic cells of mantle epithelium; similarity between these cells and growth cells can be seen. H\&E, 200x

An incomplete epithelial covering of the growth, necrosis and detachment of the cells in marginal areas of the tumor (Fig. 3a), and numerous cells with hyperchromic or pycnotic nuclei in the body of the tumor indicate that the growth on the mantle was probably in a state of chronic irritation and/or injury. There were no indications of inflammation of the central areas of the Modiolus kurilensis mantle, but irritation of the epithelium covering was obvious.

Irritation of the mantle epithelium may be related to the greatly polluted conditions of the mussel habitat (Elyakov 1992) and the ability of these organisms to store high concentrations of heavy metals in their soft tissues (Shulkin \& Kavun 1995). The sampling areas in Amursky Bay had a low oxygen content and high levels of suspended solid particles and pollutants including the metals $\mathrm{Mn}, \mathrm{Zn}, \mathrm{Cu}, \mathrm{Pb}, \mathrm{Cd}, \mathrm{Ni}$, petroleum and chlorinated hydrocarbons, and detergents (Khristo- forova et al. 1993, Tkalin et al. 1993, Shulkin \& Kavun 1995). One clear cellular response of mussels to heavy metal exposure is increased mucus production because mucus is one of the effective agents for the depuration of metals in mussels (Scott \& Mayor 1972, D'Silva \& Kureishy 1978, Sunila 1981, Hietanen et al. 1988, Sze \& Lee 1995). Probably, the cells of the mantle epithelium of mussels Modiolus kurilensis from highly polluted areas have to secrete higher than average amounts of mucus, which results in an increased number of subepithelial mucus glands. Tan \& Lim (1984) also assumed that the number of mucus glands in $\mathrm{Pb}-$ treated Perna viridis mussels increased. In addition, Lichtenfels et al. (1996) found that water pollution resulted in a chronic inflammatory process and high levels of mucus secretion in fish gills. We think that unknown abnormal stimuli or complex environmental stress factors (the presence of particles, heavy metals, 
hydrocarbons or detergents) may provoke hyperplastic proliferation of mucous cells under epithelium in the mantle of $M$. kurilensis. Excessive hyperplasia of subepithelial mucous cells was found in only 1 sample; however, numerous aggregates of mucous cells were observed in many mussels from Amursky Bay. Probably, the emergence of the tumor on the mussel mantle is related to a compensatory or regenerative hyperplasia of subepithelial mucous cells, although this hyperplasia is insufficient to affect the neoplasia.

\section{LITERATURE CITED}

D'Silva C, Kureishy T W (1978) Experimental studies on the accumulation of copper and zinc in the green mussel. Mar Pollut Bull 9:187-190

Elyakov GV (ed) (1992) Long-term program of nature preservation and of rational use of nature resources of Primorsky Krai till 2005. Part 2. Dalnauka, Vladivostok (in Russian)

Hietanen B, Sunila I, Kristoffersson R (1988) Toxic effects of zinc on the common mussel Mytilus edulis L. (Bivalvia) in brackish water. 1. Physiological and histopathological studies. Ann Zool Fenn 25:341-348

Khristoforova NK, Shulkin VM, Kavun VYa, Chernova EN (1993) Heavy metals in fished and cultivated species of marine mollusks in Peter the Great Bay. Dalnauka, Vladivostok (in Russian)

Lichtenfels AJFC, Lorenzi G, Guimaraes ET, Macchione M, Saldiva PHN (1996) Effects of water-pollution on the gill apparatus of fish. J Comp Pathol 115:47-60

Lobel P (1981) $\mathrm{Zn}$ in mussels from an iron pipe. Mar Pollut Bull 12:410-411

Pauley GB (1967) Four freshwater mussels (Anodonta californiensis) with pedunculated adenomas arising from the foot. J Invertebr Pathol 9:459-466

Editorial responsibility: Albert Sparks,

Seattle, Washington, USA
Pauley GB (1968) A disease in freshwater mussels (Margaritifera margaritifera). J Invertebr Pathol 12: 321-328

Pauley GB (1969) A critical review of neoplasia and tumorlike lesions in molluses. Natl Cancer Inst Monogr 31: 509-539

Pauley GB, Sayce CS (1972) An invasive epithelial neoplasm in a Pacific oyster, Crassostrea gigas. J Natl Cancer Inst 49:897-902

Pearse AGE (1968) Histochemistry. Theoretical and applied. Little, Brown and Co., Boston

Pekkarinen M (1993) A hyperplastic growth involving glandular and nervous tissues in the marsupial gill of Pseudanodonta complanata in southern Finland. J Invertebr Pathol 61:326-327

Scott DM, Major CW (1972) The effect of copper (II) on survival, respiration, and heart rate in the common blue mussel, Mytilus edulis. Biol Bull (Woods Hole) 143:679-688

Shulkin VM, Kavun V I (1995) The use of marine bivalves in heavy metal monitoring near Vladivostok, Russia. Mar Pollut Bull V 31 N 4-12:330-333

Sparks AK (1985) Synopsis of invertebrate pathology. Exclusive of insects. Elsevier Science, Amsterdam

Sunila I (1981) Toxicity of copper and cadmium to Mytilus edulis L. (Bivalvia). Ann Zool Fenn 18:213-223

Sze PWC, Lee SY (1995) The potential role of mucus in the depuration of copper from the mussels Perna viridis (L) and Septifer virgatus (Wiegmann). Mar Pollut Bull 31: 390-393

Tan WH, Lim LH (1984) The tolerance to and uptake of lead in the green mussel, Perna viridis (L). Aquaculture 42: $317-332$

Tkalin AV, Belann TA, Shapovalov EN (1993) The state of the marine environment near Vladivostok, Russia. Mar Pollut Bull 26(8):418-422

Wolf PH (1969) Neoplastic growth in two Sydney rock oysters, Crassostrea commercialis (Iredale and Roughley). Natl Cancer Inst Monogr 31:563-573

Wolf PH (1971) Unusually large tumor in Sydney rock oyster. J Nat Cancer Inst 46:1079-1084

Submitted: March 1, 1995; Accepted: April 12, 1998

Proofs received from author(s): July 15, 1998 